Araştırma Makalesi - Research Article

\title{
Merkezi Havalandırma Sistemlerine Uygun Mutfak Davlumbazına Eklenen Bariyerin Koku Çıkarma Performansına Etkisi
}

\author{
Yusuf Özbakış ${ }^{1 *}$, Fehmi Erzincanlı ${ }^{2}$ Engin Nas ${ }^{3}$, Tolga Çeviksever ${ }^{4}$ \\ Geliş / Received: 29/04/2020 \\ Revize / Revised: 14/07/2020 \\ Kabul / Accepted: 07/09/2020 \\ $\overline{o ̈ Z}$
}

\begin{abstract}
$\mathrm{Bu}$ çalı̧̧mada, merkezi havalandırma sistemlerine uygun mutfak davlumbazına eklenen bariyerin koku çıkarma performansı üzerine etkileri araştırılmıştır. Bu amaç için merkezi havalandırma sistemlerine sahip binaların mutfaklarında kullanılan davlumbaz seçilmiştir. Davlumbazın koku çıkarma performansını optimize etmek ve hem deneysel hem de istatiksel olarak incelemek için Taguchi $L_{18}\left(6^{1} \times 3^{1}\right)$ deneysel tasarım yönteminden yararlanılmıştır. Seçilen yöntem ile farklı boyutta bariyere sahip mutfak davlumbazları oluşturulmuştur. Deneyler uluslararası standartlara uygun test odasında gerçekleştirilmiştir. Deney sonuçları incelendiğinde deneylerde oluşturulan davlumbazların koku çıkarma performansı en iyi $\% 97,1$ olduğu, en kötü $\% 69,4$ olduğu görülmüsstür. Farklı boyutlara sahip bariyer ve debi parametreleri ile gerçekleştirilen deneylerin Sinyal/Gürültü oranları incelendiğinde $\mathrm{C}_{2}$ için en ideal seviyeler $\mathrm{A}_{6} \mathrm{~B}_{3}$ olarak belirlenmiştir. Anova sonuçları incelendiğinde $\mathrm{C}_{2}$ için en etkili parametrenin $\% 76,01$ ile bariyer $(\mathrm{cm})$ ve $\% 21.24$ ile debi $\left(\mathrm{m}^{3} / \mathrm{h}\right)$ olduğu tespit edilmiştir. Davlumbaza eklenen bariyer sayesinde daha yüksek koku çıkarma performansı sağlanmıştır.
\end{abstract}

Anahtar Kelimeler- Merkezi Havalandırma, Koku Çıkarma Performansl, Taguchi

\footnotetext{
1*Sorumlu yazar iletişim: yusufozbakis@hotmail.com (https://orcid.org/ 0000-0002-8439-411X)

Makine Mühendisliği, Mühendislik Fakültesi, Düzce Üniversitesi

2İletişim: fehmierzincanli@duzce.edu.tr (https://orcid.org/0000-0003-1454-8459)

Makine Mühendisliği, Mühendislik Fakültesi, Düzce Üniversitesi

3İletişim: enginnas@duzce.edu.tr (https://orcid.org/0000-0002-4828-9240)

Dr. Engin Pak Cumayeri Meslek Yüksek Okulu, Düzce Üniversitesi

4İletişim: tolgaceviksever@gmail.com (https://orcid.org/0000-0002-5900-0780)

Ar-Ge Merkezi, Silverline Endüstri A.Ş., Amasya
} 


\title{
The Effect of the Barrier Mounted on the Kitchen Hood Suitable for Central Ventilation Systems on the Odour Extraction Performance
}

\begin{abstract}
In this study, the effects of the barrier added to the kitchen hood suitable for central ventilation systems on the performance of odour extraction are investigated. For this purpose, the hood used in the kitchens of the buildings with central ventilation systems has been selected. Taguchi $\mathrm{L}_{18}\left(6^{1} \times 3^{1}\right)$ experimental design method was used to optimize the odour extraction performance of the hood and to examine it both experimentally and statistically. Kitchen hoods with different size barriers have been created with the selected method. The experiments were conducted in the test room in accordance with international standards. When the results of the experiment were examined, it was observed that the odour extraction performance of the hoods created in the experiments was the best $97.1 \%$ and the worst was $69.4 \%$. When the signal/noise ratios of the experiments carried out with different size barrier and flow parameters were examined, the most ideal levels for $\mathrm{C}_{2}$ were determined as $\mathrm{A}^{6} \mathrm{~B}^{3}$. When the Anova results were examined, it is determined that the most effective parameter for $\mathrm{C}_{2}$ was barrier $(\mathrm{cm})$ with $76.01 \%$ and flow rate $\left(\mathrm{m}^{3} / \mathrm{h}\right)$ with $21.24 \%$. By means of the barrier added to the hood, higher odour extraction performance has provided.
\end{abstract}

Keywords- Central Ventilation, Odour Extraction Performance, Taguchi 


\section{I.INTRODUCTION}

Ventilation is the introduction of clean air and circulation while removing the contaminated air from the environment. The main purpose of ventilation systems is to create optimum conditions by taking into account the air quality and thermal comfort indoors, health, comfort, and productivity for the people in the environment [1].

Today, there are various ventilation strategies in various European countries. In some countries, uncontrolled air leakage and window opening are the only ventilation, while in some countries, ventilation systems are used. In countries with colder climates, only exhaust or balanced exhaust, heat recovery units or mechanical systems have been installed [2,3].

The impact of energy reserves on ventilation rates began in the United States in 1973 with the Arab Oil Embargo. This has led to an increase in energy costs and thus an increase in the heating of buildings. The result of this was the reduction of building ventilation. The decrease in ventilation rates in recent years has increased the prevalence of asthma (the prevalence of the disease in the society) in industrialized countries. In this case, it coincides with the increase in allergic diseases over time $[4,5]$.

Interest in hoods has increased recently in catching polluted air for industrial and civil applications. Hoods are used in many application areas (chemical industry, food industry, industrial warehouses and buildings, etc.) to remove exhaust gases, dirty or contaminated air, and humid air from the environment [6].

The main task of kitchen ventilation is to adequately remove the heat and pollutants resulting from cooking from the area where it is located, with a minimum air flow rate. Effective kitchen ventilation can reduce the exposure of people in the kitchen to air pollutants caused by cooking [7]. Cooking has been considered the main source of indoor pollutants. Visible vapors are produced during the cooking process. These usually include submicrometer particles, such as oil droplets, combustion products, steam, and condensed organic pollutants [8].

As the ventilation rate in kitchens increases, the final pollutant concentration decreases. However, if the hot air in the interior is expelled and the energy expense for ventilation is considered, this means a loss of energy. Therefore, an acceptable 'comfort' and 'confidence' state of steady state concentration must be established. In such a case, less ventilation and therefore less energy needs will be met. However, removal of contaminated air supplies is a more effective way than diluting pollutant concentrations through ventilation to control indoor air quality [9].

In the kitchens, the dirty air produced during cooking processes accumulates in areas with inappropriate ventilation systems. This accumulated polluted air can be bothersome not only for the occupants of the kitchen, but also for those who are in adjacent rooms. Therefore, it is clear that sufficient ventilation system is required to efficiently remove fumes, volatile organic compounds, grease particles and steam from the kitchen area [10].

In this study, the odour extraction performance optimization study of adding barriers to the kitchen hoods of buildings with central ventilation systems was carried out. The experimental design was created according to the Taguchi $\mathrm{L}_{18}\left(6^{1} \times 3^{1}\right)$ orthogonal method. The signal/noise $(\mathrm{S} / \mathrm{N})$ ratio and ANOVA analyzes of the results obtained from the experiments were carried out in order to determine the parameters for determining the ideal hood and to decide which parameter is the most effective among these parameters. By means of the mathematical model to be created with regression analysis, it is aimed to eliminate energy consumption and time loss by predicting the output results of the hood to be produced with different values with the same input parameters.

\section{II.MATERIALS AND METHODS}

In the kitchens, more efficient and higher performance hoods are required in order to optimally discharge the heat, pollutant air and pollutant gases generated during cooking. Recently, interest in the ventilation performance of kitchen hoods has increased [11]. An inefficient system in filtering and draining the air in the environment poses a risk to the health of all people in the cooking zone [12]. One way to deal with these situations is to increase the performance of hoods used in kitchens. 

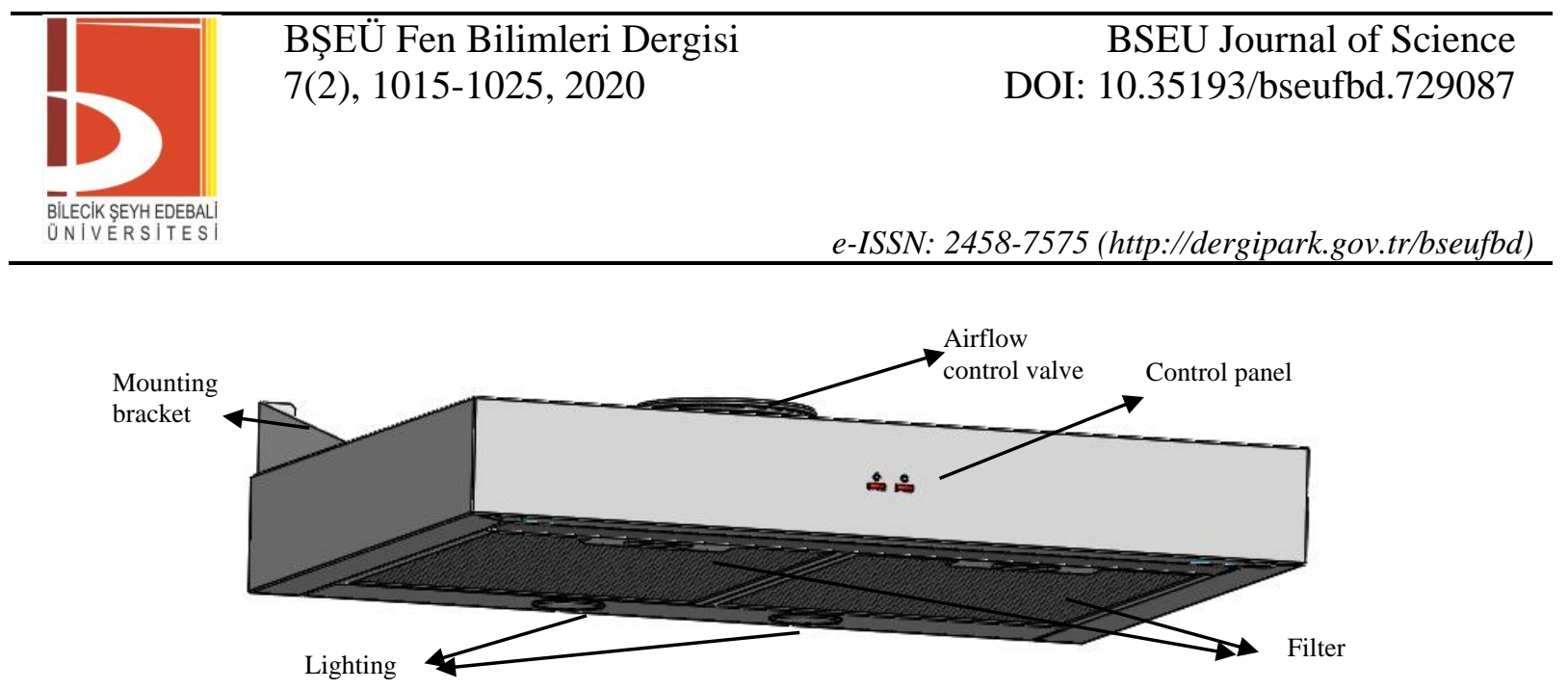

Figure 1. The hood used in the experiment.

\section{A. Hood Flow Adjustment}

Hoods use the pressure difference to remove smoke, vapors and harmful gases from the cooking space [13]. The central fan motor used in the central ventilation system creates negative pressure on the hood. By means of the pressure difference formed on the hood, air aspiration (air extraction) is performed. The amount of this air is adjusted by the air flow control valve on the hood. The airflow chart of the hood we use in the experiments is shown in Figure 2. This graph shows the airflow corresponding to the negative pressure created on the hood according to the airflow control valve positions in the hood. There are 5 different ventilation positions (F1, F2, F3, F4, F5) in the hood used. F1, F2, F3, F4 and F5 indicate a 35\%, 55\%, 75\%, $90 \%$ and $100 \%$ of opening, respectively. These positions indicate the opening amount of the air flow control valve on the hood.

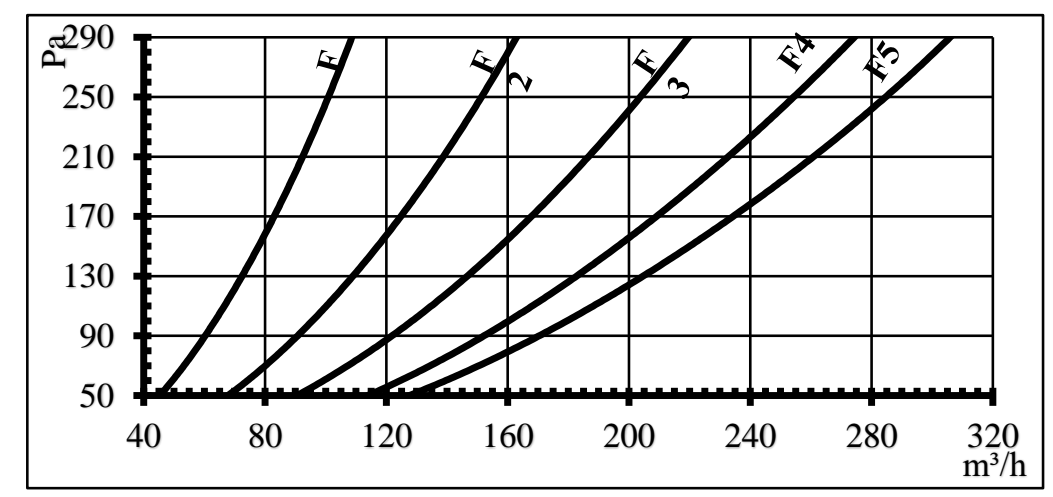

Figure 2. Air flow graph of the hood.

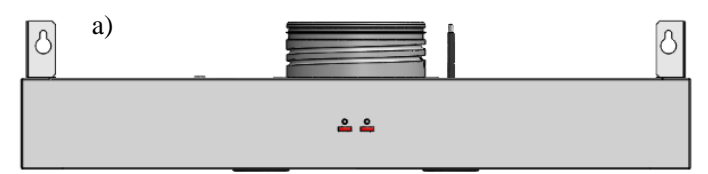

b)
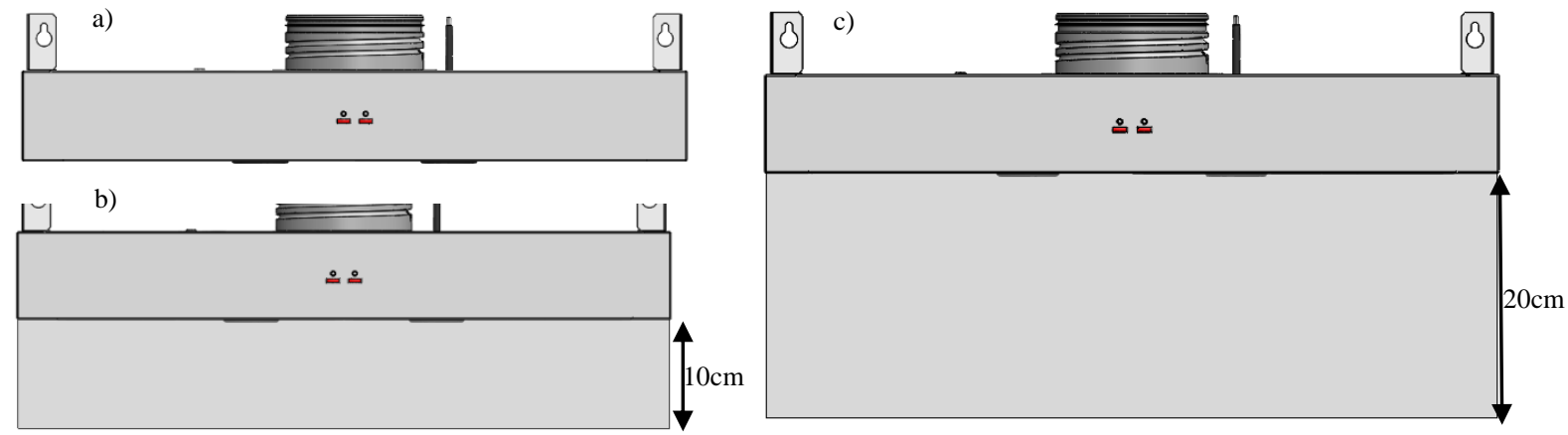

Figure 3. Hoods. a) Without barrier, b) $10 \mathrm{~cm}$ with Barrier, c) $20 \mathrm{~cm}$ with Barrier. 
6 different airflow values and the central ventilation system kitchen hood with 3 different barrier sizes were chosen for the experiments. 3 different kitchen hoods created for the experiments are shown in Figure 3. Taguchi $\mathrm{L}_{18}$ experimental design method was used to create the experiment design with the selected parameters. The test parameters and level values are shown in Table 1 and the design of the experiment is shown in Table 2.

Table 1. Parameters and levels used in the experimental study.

\begin{tabular}{lccccccc}
\hline \multirow{2}{*}{ Factor } & \multicolumn{8}{c}{ Level } \\
\cline { 2 - 8 } & Code & $\mathbf{1}$ & $\mathbf{2}$ & $\mathbf{3}$ & $\mathbf{4}$ & $\mathbf{5}$ & $\mathbf{6}$ \\
\hline Airflow $\left(\mathrm{m}^{3} / \mathrm{h}\right)$ & A & 185 & 210 & 235 & 260 & 285 & 310 \\
Barrier $(\mathrm{cm})$ & B & 0 & 10 & 20 & & & \\
\hline
\end{tabular}

Table 2. Taguchi $\mathrm{L}_{18}$ experiment design.

\begin{tabular}{ccc}
\hline \multicolumn{3}{c}{ Input Parameters } \\
\hline No & A & B \\
\hline $\mathbf{1}$ & 185 & 0 \\
$\mathbf{2}$ & 210 & 0 \\
$\mathbf{3}$ & 235 & 0 \\
$\mathbf{4}$ & 260 & 0 \\
$\mathbf{5}$ & 285 & 0 \\
$\mathbf{6}$ & 310 & 0 \\
\hline
\end{tabular}

\begin{tabular}{ccc}
\hline \multicolumn{3}{c}{ Input Parameters } \\
\hline No & A & B \\
\hline $\mathbf{7}$ & 185 & 10 \\
$\mathbf{8}$ & 210 & 10 \\
$\mathbf{9}$ & 235 & 10 \\
$\mathbf{1 0}$ & 260 & 10 \\
$\mathbf{1 1}$ & 285 & 10 \\
$\mathbf{1 2}$ & 310 & 10 \\
\hline
\end{tabular}

\begin{tabular}{ccc}
\hline \multicolumn{3}{c}{ Input Parameters } \\
\hline No & A & B \\
\hline $\mathbf{1 3}$ & 185 & 20 \\
$\mathbf{1 4}$ & 210 & 20 \\
$\mathbf{1 5}$ & 235 & 20 \\
$\mathbf{1 6}$ & 260 & 20 \\
$\mathbf{1 7}$ & 285 & 20 \\
$\mathbf{1 8}$ & 310 & 20 \\
\hline
\end{tabular}

\section{B. Odour Extraction Performance Measurement}

The test procedure for measuring the odour extraction performance of central ventilation hoods is specified in standard EN 13141-3. The catch efficiency $\left(\mathrm{O}_{\mathrm{f}}\right)$ calculation of the kitchen hoods was made as in Equation 1 in accordance with the EN 13141-3 standard. In the equation, $\mathrm{C}_{1}$ (ppm) refers to the concentration of methyl ethyl ketone (MEK) in the test chamber when the hood is not working and $\mathrm{C}_{2}(\mathrm{ppm})$ refers to the concentration of the MEK while the hood is operating [14].

$$
O_{f}=\frac{C_{1}-C_{2}}{C_{1}} x 100
$$

For experiments, firstly 300 grams of distilled water and 12 grams of methyl ethyl ketone (MEK) were mixed and the solution was formed. 100 grams of the previously prepared solution was taken and added to the dosing unit and then dripped into experiment pot heated to $170^{\circ} \mathrm{C}$ for 10 minutes. After 10 minutes, the evaporated solution was evenly distributed throughout the room by means of a fan with an air flow of $250 \mathrm{~m}^{3} / \mathrm{h}$ placed in the center of the room. When the value is stable, the concentration $\left(\mathrm{C}_{1}\right)$ of the methyl ethyl ketone in the test chamber was measured. Before the second stage, the test chamber was ventilated until the MEK concentration in the test chamber was less than $1 \%$. In the second stage, the experiment hood, whose flow rate was adjusted before, was operated. Then 100 grams of MEK mixture was added to the dosing pump and dripped into experiment pot heated to $170^{\circ} \mathrm{C}$ for 10 minutes. At the end of 10 minutes, the hood was turned off and the fan in the room was operated, allowing the evaporated solution to be distributed evenly inside the room. When the value was stabilized, the MEK concentration $\left(C_{2}\right)$ was measured in the test chamber. $C_{2}$ measurement was done separately for 18 tests with different flow rates and barriers determined before. Before each measurement, the test chamber was ventilated until the methyl ethyl ketone (MEK) concentration was less than $1 \%$. Based on the experimental test data obtained from multiple points in the kitchen, the capture efficiency calculation was made. 


\begin{tabular}{|c|c|c|}
\hline & $\begin{array}{l}\text { BŞEÜ Fen Bilimleri Dergisi } \\
7(2), 1015-1025,2020\end{array}$ & $\begin{array}{r}\text { BSEU Journal of Science } \\
\text { DOI: } 10.35193 / \text { bseufbd.729087 }\end{array}$ \\
\hline IERS & & 88-7575 (http://dergipark.gov.tr/bseufbd) \\
\hline
\end{tabular}
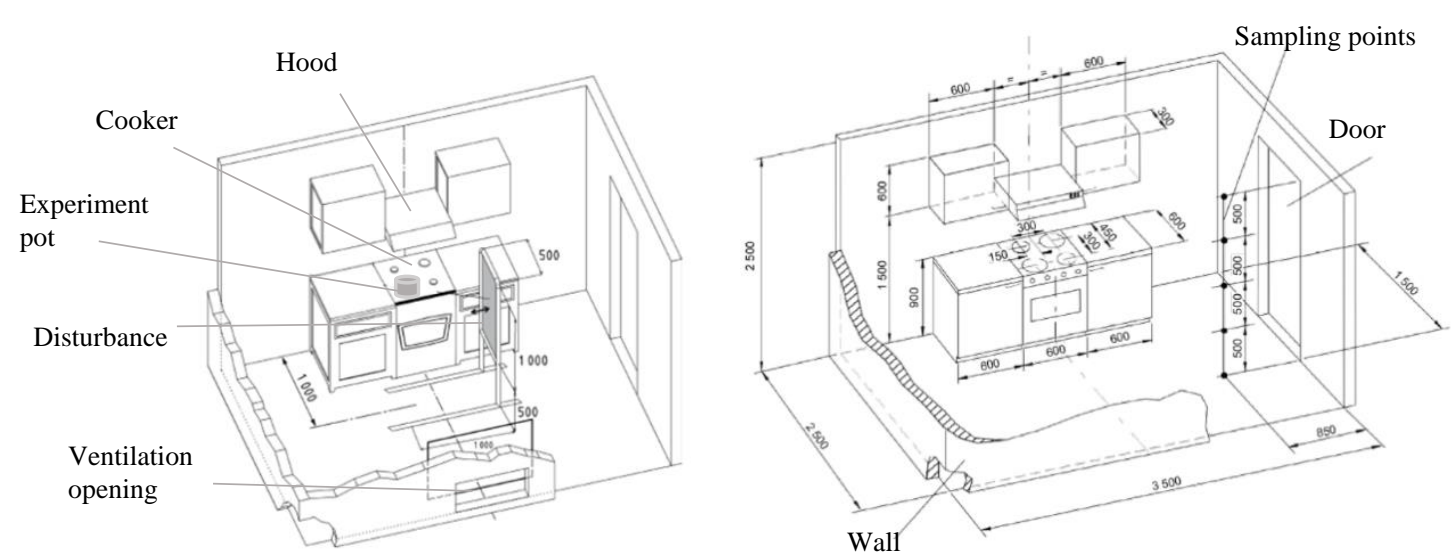

Figure 3. Odour extraction performance test chamber [14].

The experiments of three different hoods created by adding different air barriers to the kitchen hoods used in central ventilation systems were carried out in the test room with international standards and European standards shown in Figure 3 [14,15]. The lowest odour extraction performance value measured as a result of the experiments was measured in Figure $4 \mathrm{a}$ and the largest odour extraction performance value was measured in Figure 4c.

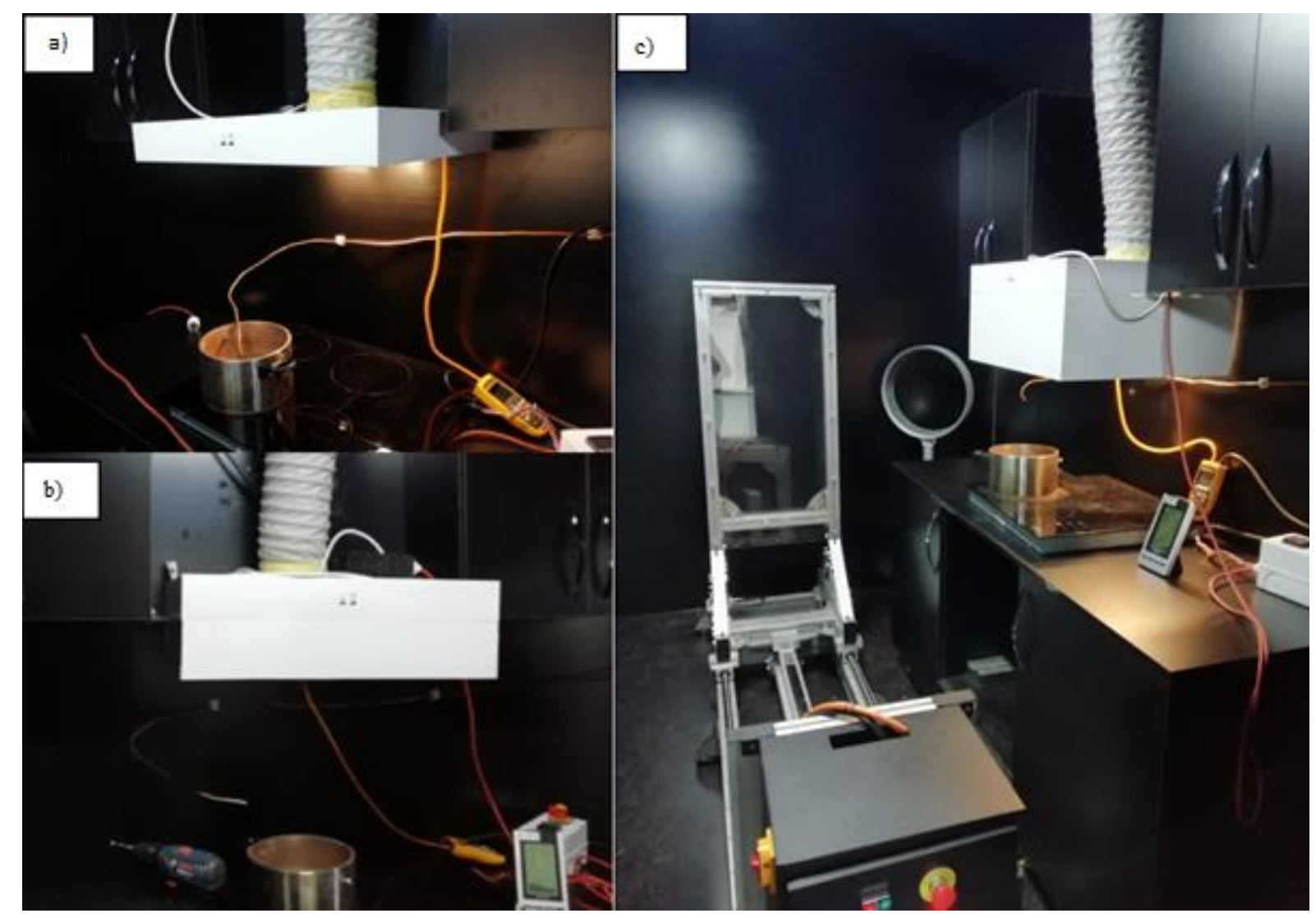

Figure 4. Odour extraction performance test. a) Without barrier, b) $10 \mathrm{~cm}$ with Barrier, c) $20 \mathrm{~cm}$ with Barrier. 


\section{III.EXPERIMENTAL RESULTS}

\section{A. Taguchi Experimental Design}

Taguchi $\mathrm{L}_{18}$ was created using the experimental design method, $3^{1} \times 6^{1}(18)$ experiments shown in Table 1 were made by creating kitchen hoods with different barrier sizes. The performance values of the odour extraction were calculated by means of experimental measurements for different arrangements of the extractor hood. The MEK concentration while the hood is operating $\left(\mathrm{C}_{2}\right)$, odour extraction performance and the $\mathrm{S} / \mathrm{N}$ ratios of the experimental results calculated by the Taguchi method are shown in Table 3.

Table 3. Experimental parameters and results.

\begin{tabular}{|c|c|c|c|c|c|c|c|}
\hline \multicolumn{3}{|c|}{ Imput Parameters } & \multicolumn{3}{|c|}{ Output Parameters } & \multicolumn{2}{|c|}{ S/N Ratios } \\
\hline $\begin{array}{c}\text { Deney } \\
\text { No }\end{array}$ & $\begin{array}{c}\text { Airflow } \\
\left(\mathbf{m}^{3} / \mathbf{h}\right) \\
\mathbf{A}\end{array}$ & $\begin{array}{c}\text { Barrier } \\
(\mathbf{c m}) \\
\text { B }\end{array}$ & $\mathrm{C}_{1}$ (ppm) & $\begin{array}{l}\text { lethyl ketone } \\
\text { centration } \\
\mathbf{C}_{2}(\mathbf{p p m})\end{array}$ & $\begin{array}{c}\text { Odour } \\
\text { extraction } \\
\text { performance } \\
(\%) \\
\end{array}$ & $\mathrm{C}_{2}(\mathrm{ppm})$ & $\begin{array}{c}\text { Odour } \\
\text { extraction } \\
\text { performance } \\
(\%) \\
\end{array}$ \\
\hline 1 & 185 & 0 & \multirow{18}{*}{55.5} & 17 & 69.4 & -24.61 & 36.83 \\
\hline 2 & 185 & 10 & & 9.5 & 82.9 & -19.55 & 38.37 \\
\hline 3 & 185 & 20 & & 5.1 & 90.8 & -14.15 & 39.16 \\
\hline 4 & 210 & 0 & & 15.9 & 71.4 & -24.03 & 37.07 \\
\hline 5 & 210 & 10 & & 7.5 & 86.5 & -17.50 & 38.74 \\
\hline 6 & 210 & 20 & & 4.4 & 92.1 & -12.87 & 39.29 \\
\hline 7 & 235 & 0 & & 11.4 & 79.5 & -21.14 & 38.01 \\
\hline 8 & 235 & 10 & & 6.3 & 88.6 & -15.99 & 38.95 \\
\hline 9 & 235 & 20 & & 3.3 & 94.1 & -10.37 & 39.47 \\
\hline 10 & 260 & 0 & & 10.7 & 80.7 & -20.59 & 38.14 \\
\hline 11 & 260 & 10 & & 5.1 & 90.8 & -14.15 & 39.16 \\
\hline 12 & 260 & 20 & & 2.4 & 95.7 & -7.60 & 39.62 \\
\hline 13 & 285 & 0 & & 10.5 & 81.1 & -20.42 & 38.18 \\
\hline 14 & 285 & 10 & & 4.4 & 92.1 & -12.87 & 39.29 \\
\hline 15 & 285 & 20 & & 2.1 & 96.2 & -6.44 & 39.66 \\
\hline 16 & 310 & 0 & & 9.4 & 83.1 & -19.46 & 38.39 \\
\hline 17 & 310 & 10 & & 2.9 & 94.8 & -9.25 & 39.54 \\
\hline 18 & 310 & 20 & & 1.6 & 97.1 & -4.08 & 39.74 \\
\hline
\end{tabular}

The MEK concentration while the hood is operating $\left(\mathrm{C}_{2}\right)$ and odour extraction performance $\left(\mathrm{O}_{\mathrm{f}}\right)$ of the three different hoods created by adding different air barriers to the kitchen hoods used in central ventilation systems were examined. When the test results (Table 3) were examined, the MEK concentration value measured while the hood was operating was measured in experiment 18 with a minimum of as $1.6 \mathrm{ppm}$ and in experiment 1 with a maximum of as $17 \mathrm{ppm}$. When the odour extraction performance $\left(\mathrm{O}_{\mathrm{f}}\right)$ was examined, it was measured at the lowest as $69.4 \%$ in experiment 1 and the highest as $97.1 \%$ in experiment 18 . Normally, it is necessary to remove $310 \mathrm{~m}^{3} / \mathrm{h}$ of air from the environment for $83 \%$ odour extraction performance, while the same performance is provided by removing $185 \mathrm{~m}^{3} / \mathrm{h}$ of air from the environment with a hood with $10 \mathrm{~cm}$ barrier added. In other words, by adding $10 \mathrm{~cm}$ barrier to the hood, $125 \mathrm{~m}^{3} / \mathrm{h}$ of air is prevented from being removed from the environment. Considering the Northern European countries, the energy loss that will occur by removing the hot air in the environment will be prevented.

\section{B. Signal-Noise (S/N) Analysis}

The $\mathrm{S} / \mathrm{N}$ ratio is a tool that statistically measures the performance characteristics of the Taguchi method, and it is a logarithmic function of the response defined as the aim function [16-18]. In this study, since the small of MEK concentration ( $\mathrm{ppm}$ ) values measured while the hood is operating will provide a performance advantage 
in the product, "( $\mathrm{S} / \mathrm{N})$, the smallest-the best" has been chosen as the quality characteristic (distinctive feature) [19]. S/N ratios of each of the values obtained as a result of the experiment, MEK concentration (ppm) value measured while the hood is operating were calculated by Taguchi method and shown in Table 4 .

Table 4. Signal to noise ratios of hoods assembled with experiment parameters.

\begin{tabular}{rcc}
\hline \multicolumn{3}{c}{ Signal/Noise Ratios } \\
\hline \multicolumn{3}{c}{$\mathbf{C}_{2}(\mathbf{p p m})$} \\
\hline Level & $\begin{array}{c}\text { Airflow } \\
(\mathrm{m} 3 / \mathrm{h})\end{array}$ & Barrier $(\mathrm{cm})$ \\
\hline 1 & -19.438 & -21.708 \\
2 & -18.133 & -14.885 \\
3 & -15.832 & $\mathbf{- 9 . 2 5 4}$ \\
4 & -14.114 & \\
5 & -13.246 & \\
6 & $\mathbf{- 1 0 . 9 3 1}$ & 12.455 \\
Delta & 8.507 & 1 \\
Rank & 2 & \\
\hline & & \\
\hline
\end{tabular}

The analyzes were performed out according to the smallest best and largest best purpose function. The results are shown in table 4 . The ideal parameter for MEK concentration $\left(\mathrm{C}_{2}\right)$ values measured while the hood is operating is observed as Level 6 for air flow and Level 3 for the barrier and is graphically shown in Figure 5.

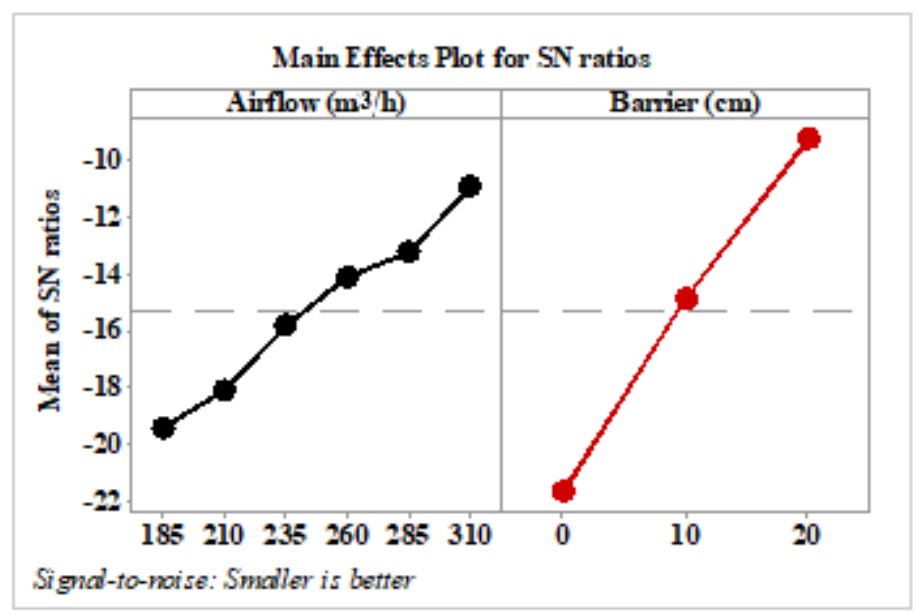

Figure 5. The main effects plot for $\mathrm{C} 2$ (ppm) signal to noise ratios.

\section{Anova}

In this study, variance analysis was used to determine the numerical effect (\%) of the parameters affecting the MEK concentration $\left(\mathrm{C}_{2}\right)$ measured while the hood is operating. ANOVA is a method that is used statistically to determine the interactions of control factors among each other [20]. The analysis performed in this study was conducted at the level of $95 \%$ confidence and $5 \%$ significance [21]. Table 5 shows the numerical effects of the air barrier and air flow rate selected in the experiments on the MEK concentration $\left(\mathrm{C}_{2}\right)$ measured 
while the hood is operating and odour extraction performance $\left(\mathrm{O}_{\mathrm{f}}\right)$. The most effective process parameter on the MEK concentration $\left(\mathrm{C}_{2}\right)$ measured while the hood is operating had been barrier with $76 \%$.

Table 5. Anova variance analysis for $\mathrm{C}_{2}(\mathrm{ppm})$.

\begin{tabular}{rcrrrrrr}
\hline \multicolumn{7}{c}{$\mathbf{C}_{\mathbf{2}}(\mathbf{p p m})$} \\
\hline Source & DF & Seq SS & Contribution & Adj SS & Adj MS & F-Value & P-Value \\
\hline Airflow $\left(\mathrm{m}^{3} / \mathrm{h}\right)$ & 5 & 76.936 & $21.24 \%$ & 76.936 & 15.387 & 15.48 & 0.0001981 \\
Barrier $(\mathrm{cm})$ & 2 & 275.271 & $\mathbf{7 6 . 0 1 \%}$ & 275.271 & 137.636 & 138.44 & 0.0000001 \\
Error & 10 & 9.942 & $2.75 \%$ & 9.942 & 0.994 & & \\
Total & 17 & 362.149 & $100.00 \%$ & & & \\
\hline \multicolumn{7}{c}{ R-sq: $97.25 \%$} \\
\hline
\end{tabular}

\section{Regression Analysis and Estimated Results}

Regression analysis is performed for modeling and analysis of various variables that have a relationship between one dependent variable and one or more independent variables [20]. The MEK concentration $\left(\mathrm{C}_{2}\right)$ measured while the hood is operating of the experiments created with three different hoods and 6 different flows were calculated by regression analysis. The estimated equations calculated linearly are shown in Table 6.

Table 6. Estimated equations for experimental results.

\begin{tabular}{ll}
$\mathrm{C}_{2}(\mathrm{ppm}) \quad=23.52-0.04712$ airflow -0.4667 Barrier \\
\hline
\end{tabular}

\section{IV.CONCLUSIONS}

In this study, the parameters affecting the odour extraction performance of the kitchen hoods of the buildings with central ventilation system were examined experimentally and statistically and the results were given as items.

- The odour performance value of hoods created by adding different size air barrier was measured as $69.4 \%$ (smallest) and $97.1 \%$ (largest).

- When the test results are examined, it is observed that there is a $30.8 \%$ improvement in the hood odour extraction performance for the lowest air flow value of the hood to be created with the selected air barrier. For the highest air flow value, it is observed that there is a $16.8 \%$ improvement in hood odour extraction performance.

- Higher odour extraction performance has been achieved by means of the barrier added to the hood. When the odour extraction performance are examined, it is observed that the barrier added to the hood is more effective in low airflow value.

- $\quad \mathrm{C}_{2}$ value of hoods created by adding different size air barrier was measured as $1.6 \mathrm{ppm}$ (smallest) and 17.0 ppm (largest).

- When the Anova results are examined, it is observed that the most effective parameter for $\mathrm{C}_{2}$ (ppm) is barrier $(\mathrm{cm})$ with rate $76.01 \%$ and flow $\left(\mathrm{m}^{3} / \mathrm{h}\right)$ with rate $21.24 \%$.

- The ideal parameters for $\mathrm{C}_{2}$ according to signal noise ratios are observed Level 6 for air flow and Level 3 for barrier.

- In subsequent studies, different airflow control valve designs and accordingly air flow, odour, acoustic, and vibration emission measurements of the hoods are recommended. 


\section{ACKNOWLEDGMENT}

Thanks to Silverline Endüstri A.Ș. and its employees for their support, and also to R\&D director Semra ASLAN for their support.

\section{REFERENCES}

[1] Liddament, M. (1996). A Guide to Energy Efficient Ventilation, Air Infiltration and Ventilation Centre, Sint-Stevens-Woluwe. Belgium, 85, 9.

[2] Concannon, P. (2002). Technical Note AIVC 57: Residential Ventilation. Air Infiltration and Ventilation Center, Brussels.

[3] Schild, P. G. (2007). State-of-the-art of low-energy residential ventilation. Contributed Report 7.

[4] Lundbäck, B. (1998). Epidemiology of rhinitis and asthma. Clinical and experimental allergy: journal of the British Society for Allergy and Clinical Immunology, 28, 3-10.

[5] Heinrich, J. (2011). Influence of indoor factors in dwellings on the development of childhood asthma. International journal of hygiene and environmental health, 214.1, 1-25.

[6] Jacobs, P., Cornelissen, E. \& Borsboom, W. (2016). Energy efficient measures to reduce PM2, 5 emissions due to cooking. Indoor Air conference, TNO, Delft, Netherlands.

[7] Stratton, J.C. \& Singer, B.C. (2014). Addressing Kitchen Contaminants for Healthy. Low-energy Homes.

[8] Abdullahi, K.L., Delgado-Saborit, J.M. \& Harrison, R.M. (2013). Emissions and indoor concentrations of particulate matter and its specific chemical components from cooking: a review. Atmospheric Environment. 71, 260-294.

[9] World Health Organization. (1989). Indoor air quality: organic pollutants; EURO report and studies, vol. 111. Regional Office for Europe: Copenhagen, Denmark.

[10] Abanto, J. \& Reggio, M. (2006). Numerical investigation of the flow in a kitchen hood system. Building and environment, 41(3), 288-296.

[11] Pinelli, M. \& Suman, A. (2014). A numerical method for the efficient design of free opening hoods in industrial and domestic applications. Energy, 74, pp. 484-493.

[12] Lunden, M. M., Delp, W. W., \& Singer, B. C. (2015). Capture efficiency of cooking-related fine and ultrafine particles by residential exhaust hoods. Indoor Air, 25(1), 45-58.

[13] Cicconi, P., Germani, M., Landi, D., \& Russo, A. C. (2017). A design methodology to predict the product energy efficiency through a configuration tool. In Advances on Mechanics, Design Engineering and Manufacturing (pp. 1095-1105). Springer, Cham.

[14] European Norm. (2017). Ventilation for buildings - Performance testing of components/products for residential ventilation - Part 3: Range hoods for residential use without fan. EN 13141-3.

[15] The International Electrotechnical Commission. (2005). Household range hoods - Methods for measuring performance. IEC 61591.

[16] Nas, E., \& Öztürk, B. (2018). Optimization of surface roughness via the Taguchi method and investigation of energy consumption when milling spheroidal graphite cast iron materials. Materials Testing, 60(5), 519525 . 
[17] Kivak, T. (2014). Optimization of surface roughness and flank wear using the Taguchi method in milling of Hadfield steel with PVD and CVD coated inserts. Measurement, 50, 19-28.

[18] Aslantas, K., Ekici, E., \& Cicek, A. D. E. M. (2018). Optimization of process parameters for micro milling of Ti-6Al-4V alloy using Taguchi-based gray relational analysis. Measurement, 128, 419-427.

[19] Akkuş, H., \& Yaka, H. (2018). Optimization of Turning Process By Using Taguchi Method. Sakarya Üniversitesi Fen Bilimleri Enstitüsü Dergisi, 22(5), 1444-1448.

[20] Nas, E., \& Gökkaya, H. (2017). Experimental and Statistical Study on Machinability of the Composite Materials with Metal Matrix Al/B 4 C/Graphite. Metallurgical and Materials Transactions A, 48(10), 50595067.

[21] De Paiva, A. P., Gomes, J. H. F., Peruchi, R. S., Leme, R. C., \& Balestrassi, P. P. (2014). A multivariate robust parameter optimization approach based on Principal Component Analysis with combined arrays. Computers \& Industrial Engineering, 74, 186-198. 